\title{
Measure nicotine dependence by the fagerström test for nicotine dependence
}

\author{
Grau de dependência nicotínica por meio do teste de fagerström para dependência de nicotina
}

\author{
Caroline Francieli WEBER ${ }^{1}$ \\ Patrícia HATSCHBACH ${ }^{1}$ \\ Sílvia Ataide PITHAN² \\ Angela Isabel dos Santos DULLIUS 3
}

\section{ABSTRACT}

\section{Objective}

To assess the level of nicotine dependence of smokers in a university dental clinic in southern Brazil using the Fagerström Test for Nicotine Dependence and identify those who would like to quit smoking.

\section{Methods}

A cross-sectional study was carried out with 93 Dental School patients, who underwent a face-to-face interview with four researchers. Data was analysed using descriptive statistics and the Chi-Square test with a significance level of $5 \%$.

\section{Results}

The mean age of the smokers was 47.90 and most had had up to eight years of schooling, and had a family income of less than 1,000 Brazilian Reais. The degree of nicotine dependence was classified, by the mean, $4.45 \pm 2.53$ points $( \pm S D)$. There was a significant correlation between nicotine dependence and the number of cigarettes smoked per day.

\section{Conclusion}

The $1 \%$ sodium hypochlorite solution caused least damage to the denture structure, not leading to decrease of the superficial microhardness.

Indexing terms: Smoking. Smoking cessation Tobacco.

\section{RESUMO}

\section{Objetivo}

Avaliar o grau de dependência nicotínica de pacientes fumantes utilizando o Teste de Fagerström para Dependência de Nicotina e o desejo de abandonar o hábito do tabagismo.

\section{Métodos}

Trata-se de um estudo transversal analítico, com amostragem probabilíistica, composta por 93 adultos de ambos os sexos. Utilizou-se o Teste de Fagerström para Dependência de Nicotina e as informações foram coletadas por quatro pesquisadores. Os dados foram analisados por meio de estatística descritiva e inferencial (Qui-quadrado), sendo empregado o nível de significância de 5\%).

\section{Resultados}

Os fumantes apresentaram média de idade de 47,90 anos, sendo que a maioria possui até ensino fundamental e renda familiar de 1000 reais. O grau de dependência nicotínica foi classificado, em média, como escore de 4,45 $\pm 2,53$ pontos ( \pm dp). Houve associação entre nível de dependência e número de cigarros fumados por dia.

\section{Conclusão}

Pode-se concluir que $36,6 \%$ da amostra apresentam dependência elevada ou muito elevada. Esse grupo pode necessitar de terapia medicamentosa para auxiliar na cessação do tabagismo, salientando-se a importância dos grupos de apoio com esse fim, uma vez que 95\% da amostra gostaria de parar de fumar.

Termos de indexação: Hábito de fumar. Abandono do hábito de fumar. Tabaco.

\footnotetext{
${ }^{1}$ Universidade Federal de Santa Maria, Faculdade de Odontologia. Santa Maria, RS, Brasil.

${ }^{2}$ Universidade Federal de Santa Maria, Departamento de Estomatologia. Rua Floriano Peixoto, 1184, Prédio da Antiga Reitoria, Sala 116, Centro, Santa Maria, Rio Grande do Sul, Brasil. Santa Maria, RS, Brasil. Correspondência para / Correspondence to: AS PITHAN. E-mail: <silpithan@yahoo.com.br>.

${ }^{3}$ Universidade Federal de Santa Maria, Departamento de Estatística. Santa Maria, RS, Brasil.
} 


\section{INTRODUCTION}

Smoking is a significant public health problem throughout the world since, according to the World Health Organization (WHO), around 6 million people die every year as a result of tobacco use and 1.2 billion, in other words one third of the world's population of adults, are smokers'. In Brazil, the world's leading tobacco producer, it is estimated that around 200,000 Brazilians die every year as a consequence of problems caused by cigarettes, equivalent to 23 deaths an hour ${ }^{2}$. In the Southern region of Brazil, in 2013, the percentage of smokers over the age of 18 was $16.1 \%$, a big difference when compared to 1989 , when the figure for Brazil as a whole was $34.8 \%{ }^{3}$.

Tobacco dependence is defined as compulsive use, including the inability to go without smoking or the difficulty in giving it up ${ }^{4}$. It is known that the appearance of abstinence syndrome and/or the impulsive desire to smoke is due to the nicotine in the cigarette, a psychoactive drug that causes heavy dependence, thus making it incredibly difficult to give up the habit. While the effects of nicotine on the body include reduced appetite, improved mood, increased cardiac frequency, higher blood pressure, nausea and diarrhea, the symptoms of nicotine abstinence include intense desire, anxiety, depression, headaches, better appetite and difficulty in concentrating, which increase the chances of relapsing into the habit ${ }^{5}$.

Even with the knowledge of the harmful effects and problems that cigarettes can have on health, giving up the habit is difficult and needs to be monitored ${ }^{4}$. Health professionals, including dental surgeons, play a fundamental role in helping and guiding patients who smoke, who show an interest in stopping smoking.

Tobacco dependence is included in the International Classification of Diseases published by the World Health Organization as mental and behavioral disorders resulting from the use of psychoactive substances ${ }^{6}$. There exists a globally recognized method that evaluates the degree of nicotine dependence of an individual, namely the Fagerström Test for Nicotine Dependence (FTND) and, according to the result obtained, the most appropriate therapy can be planned.

The Fagerström Tolerance Questionnaire (FTQ), initially consisting of eight questions, was devised in 1978 to estimate nicotine dependence. An enhanced version of the scale, called the Fagerström Test for Nicotine Dependence (FTND) was then developed by Heatherton et al. in 1991, after performing studies using the $\mathrm{FTQ}^{7}$. This consists of six of the original items (nicotine content and inhalation were removed), and two mere modified, with revised punctuation (time before smoking the first cigarette and the number of cigarettes a day) ${ }^{7}$.

Applying this quick and easy-to-understand tool, scores are obtained that enable the classification of nicotine dependence into five levels: very low (zero to two points), low (three to four points), average (five points), high (six to seven points) and very high (eight to ten points).

Considering the above and given the high rate of smokers in society today, the aim of was this study evaluate the degree of nicotine dependence of patients who smoke frequenting the clinics of the dentistry course at the Federal University of Santa Maria and their desire to give up the habit, to enable planning of the most suitable treatment.

\section{METHODS}

Being a research study involving human beings, the current project was submitted for analysis by the university's Research Ethics Committee, and was duly approved, under the Certificate of Presentation for Ethical Consideration no. 12456713.8.0000.5346 and in compliance with Resolution 466/2012 .

This study was conducted in the following clinics: Cosmetic Dentistry II and III, Periodontology I and II, stomatology, integrated clinics I, II and III and the screening service of the Dentistry Course at the Federal University of Santa Maria (UFSM), in the Brazilian state of Rio Grande do Sul. The course serves around 500 adult patients each semester, who spontaneously seek it or are referred by other public or private services. The course also provides care to children, however the registration and screening are performed by the specific college course and do not form part of this number.

This was a quantitative study using the analytical, cross-sectional epidemiological method $^{9}$ by way of a questionnaire containing six closed questions on smoking habits, the Fagerström Test for Nicotine Dependence (FTND). Sociodemographic and economic data were also collected (sex, age, level of schooling, monthly family income and occupation), data on the level of tobacco consumption, beliefs in respect of smoking and the intention to give up. These data were collected by way of a questionnaire devised by the researchers, which was submitted to the Kuder-Richardson Coefficient of Reliability $(K R-20=1)$.

The selection of interviewees was restricted to patients aged 18 or over who smoke, who were approached as they arrived or as they left their dental appointment. Smokers were defined as those who smoked every day 
(at least one a day). After reading the free and informed consent form, the patient was informed about the purpose of the study and was given the freedom to decide whether to participate or not. On agreeing to participate, the consent form was signed and the questionnaires were then answered.

The questionnaire was handed out on the days on which the Clinics were open for business, for a period of three academic semesters, depending on the availability of the researchers responsible for administering them to those patients who were suitable for the study (i.e. smokers), and with no duplication of patients, with the aim of obtaining, during this period of time, the largest possible number of interviewees. There was no discrimination in terms of sex, race or social status.

The data were tabulated and coded in Microsoft Excel spreadsheets and a database was subsequently created in EPIINFO - version 6.04. Once quantified, the results were evaluated using the Chi-square test with Yates' correction, the Fisher test and the level of statistical significance was set at $p \leq 0.05$.

\section{RESULTS}

Of the 448 individuals interviewed, 98 were smokers $(21.87 \%)$ and 93 (20.75\%) answered the FTND. The average age of the participants in the study was 47.9 years $(s d=12.75, \mathrm{Cl} 19-71)$; of these $49(52.7 \%)$ were female and 44 (47.3\%) male. Table 1 displays the sample's socioeconomic characteristics.

Table 1. Socioeconomic characteristics. Santa Maria (RS), 2013/14.

\begin{tabular}{lll}
\hline Variables & $\mathrm{n}(\%)$ & Total* \\
\hline Schooling & & \\
Incomplete elementary education (age 15) & $46(52.9 \%)$ & \\
Completed elementary education (age 15) & $18(20.7 \%)$ & \\
Completed high school & $20(2.0 \%)$ & 87 \\
Completed higher education & $3(3.4 \%)$ & \\
& & \\
Occupation & & \\
Services personnel & $56(65.9 \%)$ & \\
Retired & $11(12.9 \%)$ & \\
Farmers & $7(8.2 \%)$ & \\
Blue-collar workers, etc. & $3(3.5 \%)$ & 85 \\
Technicians & $3(3.5 \%)$ \\
Administrative personnel & $2(2.4 \%)$ & \\
Public administration personnel & $1(1.2 \%)$ & \\
Students & $2(2.4 \%)$ \\
Monthly income (Brazilian Reais) & & \\
Less than $\mathrm{R} \$ 500$ & $4(4.6 \%)$ & \\
Between $\mathrm{R} \$ 500$ and $\mathrm{R} \$ 1,000$ & $51(58.6 \%)$ & \\
Between $\mathrm{R} \$ 1.001$ and $\mathrm{R} \$ 2,000$ & $23(26.4 \%)$ & 87 \\
Between $\mathrm{R} \$ 2,001$ and $\mathrm{R} \$ 3,000$ & $6(6.9 \%)$ & \\
Over $\mathrm{R} \$ 3,000$ & $3(3.4 \%)$ & \\
\hline
\end{tabular}

Note: *The total for each variable differs due to the existence of incomplete data.
The degree of nicotine dependence received a mean score of 4.45 points $(s d=2.53)$ and a median value of 4 out of 10 (Table 2 ).

Table 2. Characteristics according to the FTQ. Santa Maria (RS), 2013/14

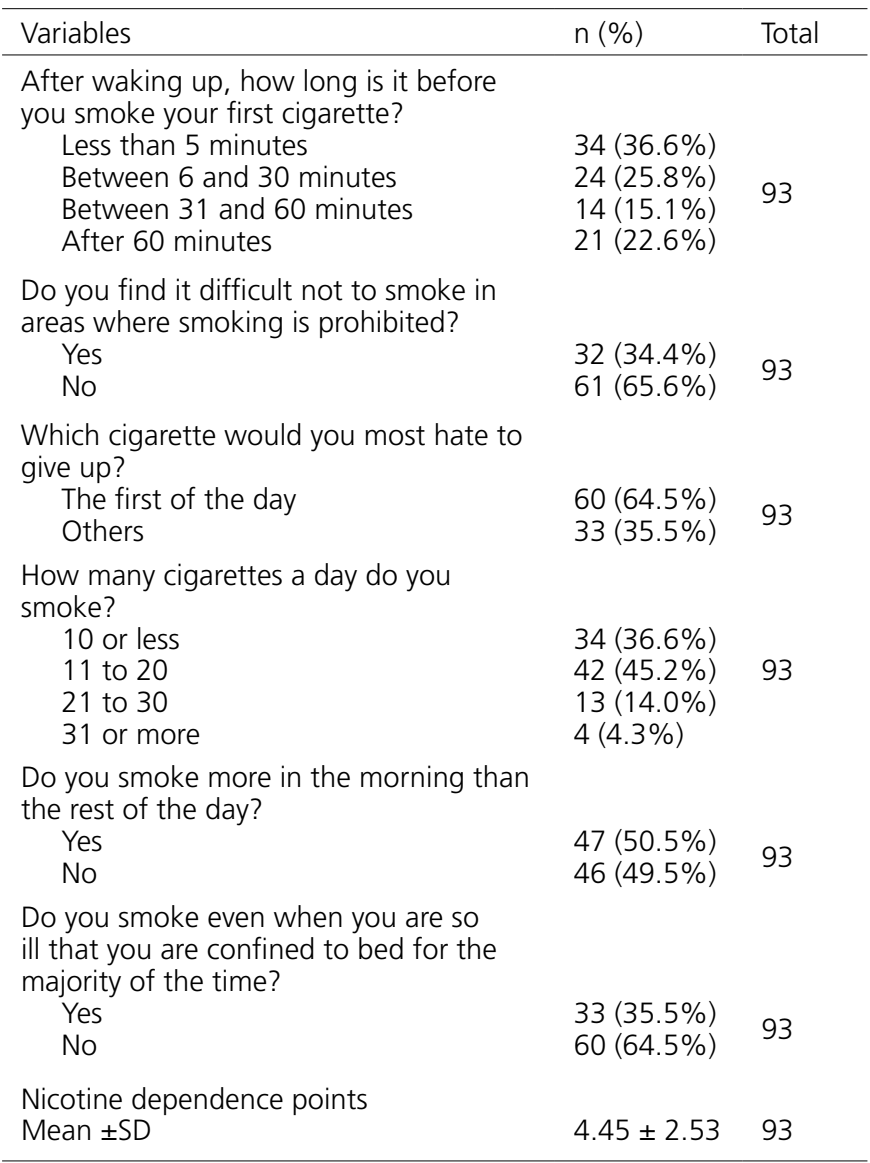

Gender was not found to be linked with nicotine dependence $(p=0.3012)$, but of the $22.6 \%$ with high dependence (greater than or equal to six points), there were twice as many females $(n=14)$ than males $(n=7)$, as shown in Table 3.

Table 3. Distribution of the degree of dependence, by sex. Santa Maria (RS), 2013/14.

\begin{tabular}{lccc}
\hline Level of dependence & Females & Males & Total \\
\hline Very low & $15(65.2 \%)$ & $8(34.8 \%)$ & $23(24.7 \%)$ \\
Low & $13(52.0 \%)$ & $12(48.0 \%)$ & $25(26.9 \%)$ \\
Medium & $3(27.3 \%)$ & $8(72.7 \%)$ & $11(11.8 \%)$ \\
High & $10(45.5 \%)$ & $12(54.5 \%)$ & $22(23.7 \%)$ \\
Very high & $8(66.7 \%)$ & $4(33.3 \%)$ & $12(12.9 \%)$ \\
Total & $49(52.7 \%)$ & $44(47.3 \%)$ & $(100.0 \%)$ \\
\hline
\end{tabular}

The total number of smokers who had very high nicotine dependence (females, for the most part), responded in the Fagerström questionnaire that they found 
it difficult not to smoke in prohibited places $(p=0.2578)$. In addition, $91.7 \%$ stated they smoked even when they are so ill that they are confined to bed and $75 \%$ smoke in excess of 20 cigarettes a day. In this group it was also found that $75 \%$ smoke more frequently in the morning than during the rest of the day. Of those with 7 points or less, $53.1 \%$ answered no to this question $(p=0.1301)$, as shown in Table 4.

Table 4. Sample distribution, according to nicotine dependence with number of cigarettes smoked per day, time taken to smoke first cigarette and if they smoke more in the morning. Santa Maria (RS), 2015.

\begin{tabular}{lcc}
\hline Variables & Dependence $\geq$ six & Dependence $<$ six \\
\hline Number of cigarettes & $11(14.5 \%)$ & $65(85.5 \%)$ \\
Up to 20 & $10(58.8 \%)$ & $7(41.2 \%)$ \\
$\quad$ More than 20 & & 0.0118 \\
Time before smoking first cigarette & $21(36.2 \%)$ & $37(63.8 \%)$ \\
$\quad$ Up to 30 minutes & $0(0 \%)$ & $35(100 \%)$ \\
$\quad$ More than 30 minutes & $16(34.0 \%)$ & $31(66.0 \%)$ \\
Do you smoke more in the morning? & $5(10.9 \%)$ & $41(89.1 \%)$ \\
Yes & & 0.2782 \\
No & & 0.0075 \\
\hline
\end{tabular}

Table 5 displays data on the level of consumption of cigarettes and habit-related mindsets.

Table 5. Characteristics in terms of the level of cigarette consumption and beliefs related to the habit of smoking. Santa Maria, 2015.

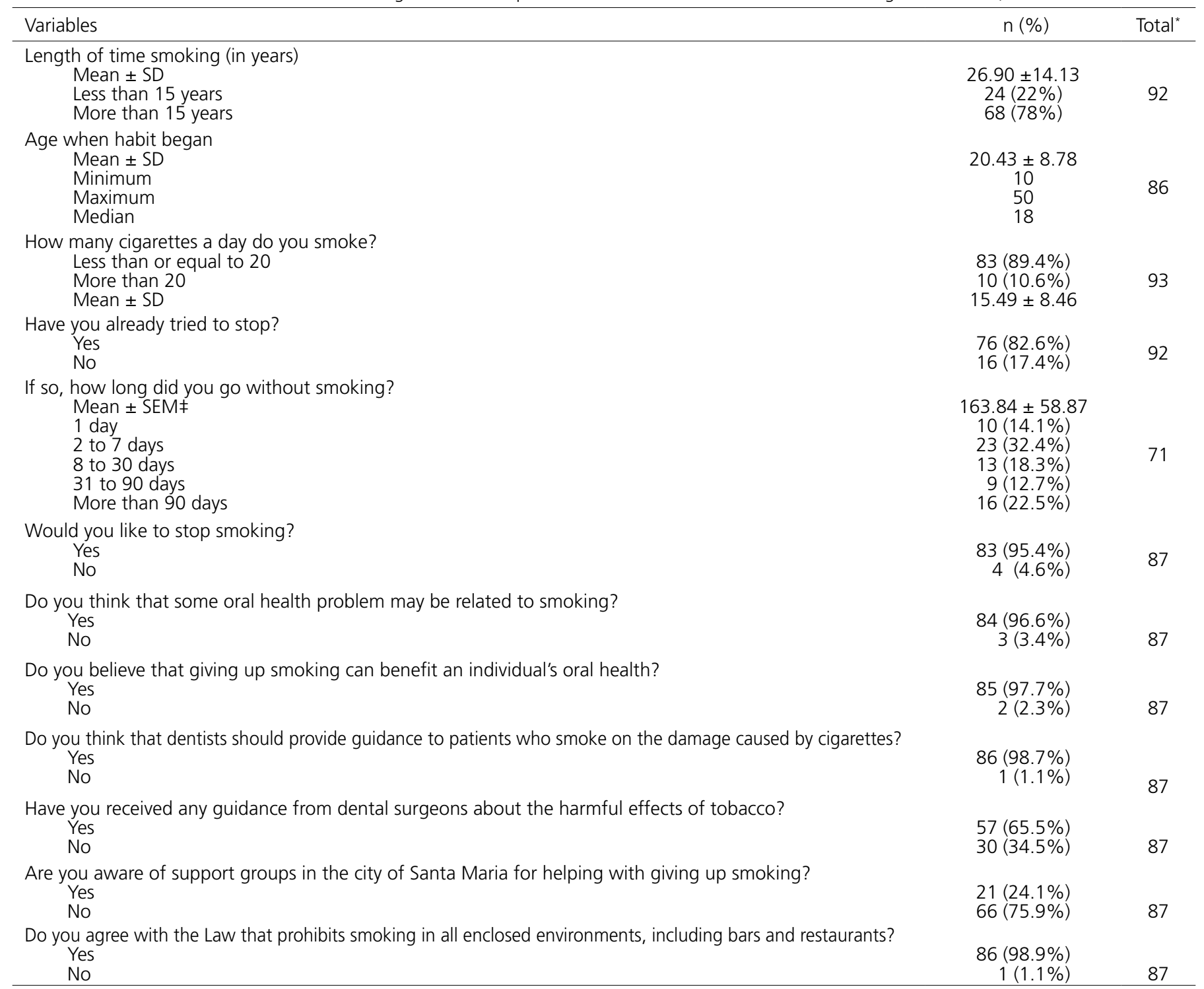

Note: $\ddagger$ Standard error of the mean. " Total value is variable as incomplete data were excluded. 


\section{DISCUSSION}

Identifying the level of nicotine dependence, using tools like the FTND, and smokers' profiles, is fundamental for the planning of treatment appropriate to each case, particularly for those who wish to kick the habit. The prevalence of smokers found in this study $(21.87 \%)$ is in agreement with the prevalence $(22.6 \%)$ in the survey carried out by the Department of Health Surveillance (2011), conducted in Porto Alegre'. In this survey, the majority presented low or very low dependence, however a significant number (36.6\% of the sample) presented high or very high dependence, which reinforces the need for drug therapy combined with other behavioral approaches. A study by Siahpush et al. ${ }^{10}$ demonstrated a significant association between the duration of drug treatment and giving up smoking. The use of drugs for at least five weeks is linked to an increase in the rates of success in quitting smoking.

The findings of this study agree to those of Fagerström and Schneider ${ }^{4}$, showing that a large proportion $(82.6 \%)$ already tried to stop smoking, without success, which may be explained by the low socioeconomic status of the sample (more than half had left school before they reached 15 years of age, and had a maximum monthly income of 1,000 Brazilian Reais) and through not being aware of the existing support groups in the city of Santa Maria, to help smokers to quit. Moreover, some social groups, with a lower socioeconomic level, rural and ethnic, have limited access to proper treatment and medication to help to give up smoking ${ }^{10}$. In contrast, another study found an association between high socioeconomic status, as measured by education, occupation and income, and high quit rates ${ }^{11}$.

In view of the above, there is a need to improve the popularization of and access to free services aimed at the cessation of smoking and nicotine replacement treatment already available under the National Health System, and also invest in measures that raise the price of cigarettes even more and consequently reduce cigarette consumption in low-income families. Murphy et al. ${ }^{12}$ already assessed the importance of increasing cigarette prices to reduce tobacco consumption, whereby smokers reduce their spending on cigarettes, emphasizing the importance of these economic policies.

Many smokers are unable to give up the habit by themselves and, to this end, therapy is available that goes from simple advice to intense behavioral help in conjunction with treatment with drugs. A brief consultation and behavioral support of a health professional are effective in providing motivation to kick the habit, as demonstrated by Caponnetto and Polosa ${ }^{13}$. The addition of drugs and nicotine replacement therapy to behavioral therapy, produces higher success rates when compared with therapies employed in a disjointed manner or in cases of unassisted cessation of smoking ${ }^{11}$. All smokers are dependent on nicotine to some degree. In cases of high levels of nicotine dependence, smokers tend to experience intense withdrawal symptoms, reinforcing the need for treatment with drugs during the first few weeks of abstinence ${ }^{13}$

Treatment aimed at giving up the habit should consider the severity of nicotine dependence, the age at which smoking consumption began, the comorbidities, motivation to give up, habit-related situations and sentiments, among others ${ }^{14}$. One form of brief approach is the 4 A's model which proposes that the professional asks all patients if they smoke (argue), advises them to stop, assists those who are motivated and accompanies all the patients ${ }^{15}$. For a more intensive intervention, setting a date for giving up the habit should be encouraged and the motives leading to the patient smoking should be appraised. To combat the ensuing void, instruct the patients to drink liquids and chew something, i.e. use oral gratification substitutes. Lastly, there should be a constant monitoring of the smoker during abstinence, reinforcing the progress and discussing the difficulties, in order to prevent relapses ${ }^{16}$.

Some smokers (12.9\%) scored over 7 for nicotine dependence (very high), which has already been identified as a risk factor for cancer, as well as being a prediction of failure in any attempt to give up smoking ${ }^{17}$. The different scores obtained through the FTND do not determine who can and who cannot receive nicotine replacement therapy, but it helps to establish the dosage and timing for the use of nicotine replacement methods, addressing in particular questions such as the number of cigarettes smoked per day and which period of the day most cigarettes are smoked. Higher scores suggest the use of a higher nicotine dosage, in contrast to those who are less dependent ${ }^{4}$.

The internal consistency of the modified model with six questions (alpha coefficient of 0.61 ) is higher than in the original model with eight questions (alpha coefficient of 0.48 ), but when compared to other tools such as the Heavy Smoking Index ( $\mathrm{HSI})$, it is the same or lower. This may be explained by the number of factors evaluated: 
one relates to the urgency to recover nicotine levels (time elapsing before smoking first cigarette; smoking more in the morning period; hating not having the first cigarette); and the other relates to the level of tobacco consumption (daily cigarette consumption; smoking even when ill; smoking in prohibited places) ${ }^{7}$.

Questions 1 to 4 of the FTND carry a higher weighting, contributing with three points out of the total. The time before smoking the first cigarette after waking up (question 1) and the dependence on nicotine show that the shorter the time before smoking the first cigarette, the greater the number of smokers belonging to the high nicotine dependence group. Due to the short half-life of nicotine, the plasma nicotine levels of very dependent smokers become exhausted as soon as they wake up. These tend to experience great discomfort if they do not smoke their first cigarette quickly in the morning ${ }^{7}$.

Findings in the present study show that half of the respondents smoked between 11 and 20 cigarettes a day and $18.3 \%$ smoked over 20 cigarettes (i.e. more than one pack). This high level of daily cigarette consumption will determine a more invasive therapy strategy for these more dependent groups, highlighting that other studies have already emphasized the connection between the dose and response of tobacco usage with illness ${ }^{18}$.

A large proportion stated that they would hate to not have their first morning cigarette, which adds 1 point to the level of nicotine dependence. Few individuals scored any points for the question referring to smoking when ill and finding it difficult not to smoke in public places. These FTQ questions may be more important for an understanding of behavior in these situations, e.g. the individual might smoke before entering these environments where smoking is prohibited and consequently not report any difficulty in abstaining. These behavioral parameters serve as a basis for individual therapy and may be useful in the discussion between professional and patient about nicotine dependence. Unfortunately, the fight against smoking is not part of students' routine treatment and training.

In 1989, Fagerström and Schneider ${ }^{4}$ already recognized that information relating to previous attempts at giving up smoking could be of predictive value and should be included in the questionnaire. In this study, the majority of participants reported previous attempts at kicking the habit (abstaining, on average, for 185 days), of whom $61.8 \%$ succeeded in not smoking for between 1 and 30 days. The longer the smoker goes without smoking (more than five days), the more probable the success in any future attempt, provided that he/she is aware of the reasons for the previous failed attempt to give up ${ }^{19-20}$.

Dental surgeons and academics can help to control smoking as they are in frequent contact with their patients and can readily identify smokers and help principally those who have the intention of giving up the habit, in respect of the deleterious effects of tobacco on oral health ${ }^{21}$.

In Porto Alegre, the state capital of Rio Grande do Sul, one can find one of the highest proportions of smokers, as well as the fact that the majority started smoking before they reached 20 years of age ${ }^{22}$, in agreement with the findings of this study. In the more economically developed cities of the Southern and Southeastern regions of Brazil, the prevalence of smoking among women is now close to that observed in men ${ }^{22}$, which is also in agreement with the results of this study.

One of the debating points concerning the FTND involves the lack of relationship to the smoker's psychological and emotional state (depression, anxiety, stress and alcohol use) at the time of the survey and the reason why he/she took up smoking. Moreover, the plasma nicotine levels may not be equivalent to nicotine dependence since individuals vary with regard to the number of receptors and sensitivity to nicotine. Some may be satisfied with low levels of nicotine in the blood and still be very dependent. The difference in metabolism and excretion may affect the response of each individual to nicotine ${ }^{4}$. Starting to smoke may be influenced by friends, curiosity or the presence of parents who smoke $\mathrm{e}^{23}$. The present study found a mean starting age somewhat higher than usual, at 20.43 years, considering that the survey did not distribute the questionnaires to those under the age of 18 , consequently throwing into doubt the starting age of youngsters today, as according to the National Cancer Institute, the average starting age is $16^{24}$.

Other means of evaluating nicotine dependence are available, such as cotinine measurement and carbon monoxide in exhaled air, which may be used in conjunction with the FTND ${ }^{15}$. Higher levels of dependence may be related to a higher consumption of nicotine and, consequently, higher levels of cotinine ${ }^{25}$.

One of the limitations of this study may be the fact that it was conducted on the premises of a teaching institution in the area of health. The prevalence of smokers may not represent what might be found in the municipality or in the state. Moreover, it was not possible to obtain the hoped for starting number of 150 smokers as it was 
found that the same patients are moving around the clinic premises for a long period of time, therefore the flow of new patients inside the clinics was not so great. In the beginning, the forecast collection period was two academic semesters, during which time around 1,000 patents would be seen by the students. Given the rate of smokers in the overall population (around 20\%), it was expected to find 200 smokers. However, a loss calculation was performed since not all the patients agreed to participate nor wished to be interviewed by the researches. Even with an extension to the study of one semester, only 93 smokers actually comprised the sample, corresponding to $20.75 \%$ of the individuals approached in the survey.

It is expected that this initial diagnosis of the number of smokers and the degree of dependence will serve as encouragement to create a support group to monitor and provide guidance to these patients who are trying to abandon the habit, which could generate significant, new data in the planning of suitable strategies for attending to this population.

\section{REFERÊNCIAS}

1. Ministério da Saúde. VIGITEL BRASIL 2011. Vigilância de Fatores de Risco e Proteção para Doenças Crônicas por Inquérito Telefônico [citado 2015 Nov. 18]. Disponível em: <http://bvsms. saude.gov.br/bvs/publicacoes/vigitel_brasil_2011_fatores_risco_ doencas_cronicas.pdf>.

2. WHO. Global health risks: mortality and burden of disease attributable to selected major risks. 2009 [citado 2015 Nov 17]. Disponível em: http://www.who.int/healthinfo/global_burden_ disease/GlobalHealthRisks_report_full.pdf.

3. IBGE. Pesquisa Nacional de Saúde 2013. [citado 2015 Nov 17]. Disponível em: http://www.ibge.gov.br/home/estatistica/ populacao/pns/2013/

4. Fagerström KO, Schneider NG. Measuring nicotine dependence: a review of the Fagerstrom Tolerance Questionnaire. J Behav Med. 1989;12(2):159-182.

5. Eriksen M, Mackay J, Schluger N, Gomeshtapeh FI, Drope J. The Tobacco Atlas. 5th ed. American Cancer Society; 2015. Cap. 7: Nicotine Delivery Systems [citado 2015 Nov. 6]. Disponível em: <http://www.tobaccoatlas.org/topic/nicotine-deliverysystems/>.

6. Organização Mundial da Saúde. CID 10 Classificação estatística internacional de doenças e problemas relacionados à saúde. $10^{\circ}$ rev. São Paulo. Universidade de São Paulo; 2008.

7. Heatherton $T$, Kozlowski $L T$, Frecker $R C$, Fagerström $K O$ The Fagerström Test for Nicotine Dependence: a revision of the Fagerström Tolerance Questionnaire. $\mathrm{Br} J$ Addict. 1991;86(9):1119-27

\section{CONCLUSION}

The present study showed that a significant percentage $(36.6 \%)$ of smokers had a high degree of dependence, low level of education and income, which reinforces the importance of making available free drug resources and support groups for an efficient approach to giving up smoking. The findings in this study are important, particularly for health professionals who are in routine contact with their patients, providing care to smokers who would like guidance on the deleterious effects of tobacco and the benefits of giving up.

\section{Collaborators}

CF WEBER e P HATSCHBACH were responsible for the project elaboration, data collection and results' analysis. SA PITHAN was in charge of the project main idea, elaboration and analysis of results. AIS DULLIUS was responsible for the research statistic analysis.

8. Conselho Nacional de Saúde (Brasil). Resolução n. 466, de 12 de dezembro de 2012. Brasília, 2012 [citado 2015 Nov 23] Disponível em: <http://www.conselho.saude.gov.br/web_ comissoes/conep/index.html>.

9. Freire MCM, Pattussi MP. Tipos de estudo. In: Estrela C. Metodologia científica: ciência, ensino, pesquisa. $2^{a}$ ed. São Paulo: Artes Médicas; 2005. p. 185-209.

10. Siahpush M, Shaikh RA, McCarthy M, Kessler AS, Tibbits $M$, Singh GK. Association between duration of use of pharmacotherapy and smoking cessation: findings from a national survey. BMJ Open. 2015;5(1):e006229. doi: 10.1136/ bmjopen-2014-006229

11. Cokkinides V, Brandi P, McMahon C, Jemal A, Glynn T, Ward E. Tobacco control in the United States - recent progress and opportunities. Ca Cancer J Clin. 2009;59(6):352-65. doi: $10.3322 /$ caac. 20037

12. Murphy JM, Shelley D, Repetto PM, Cummings KM, Mahoney MC. Impact of economic policies on reducing tobacco use among Medicaid clients in New York. Prev Med. 2003 Jul;37(1):68-70. doi: 10.1016/S0091-7435(03)00049-5

13. Caponnetto P, Polosa R. Common predictors of smoking cessation. Respir Med. 2008;102(8):1182-92. doi: 10.1016/j. rmed.2008.02.017

14. Nunes SOV, Vargas HO, Lanssoni MMBS, Castro MRP, Nunes MVA, Barbosa LR, et al. Avaliação das características clinicas dos fumantes que buscaram tratamento em Centro de Referência do Sistema Único de Saúde. Biosaúde. 2006;8(1):3-24.

15. Presman S, Carneiro E, Gigliotti A. Tratamentos nãofarmacológicos para o tabagismo. Rev Psiq Clín. 2005;32(5);267275. 
16. Reichert J, Araújo AJ, Gonçalves CMC, Godoy I, Chatkin JM, Sales MPU, et al. Diretrizes para cessação do tabagismo. J Bras Pneumol. 2008;34(10):845-80.

17. Organização Pan-Americana da Saúde. $1^{\circ}$ Congresso Internacional de Prevenção de Tabagismo. Belo Horizonte: OPAS, 2002.

18. El Hajj MSE, Kheir N, Mulla AMA, Al-Badriyeh D, Al-Kaddour A, Mahfoud ZR, et al. Assessing the effectiveness of a pharmacist delivered smoking cessation program in the State of Qatar: study protocol for a randomized controlled trial. Trials. 2015;16:65. doi: 10.1186/s 13063-015-0570-z

19. Garvey AJ, Bliss R, Hitchcock JL, Heinold JW, Rosner B. Predictors of smoking relapse among self-quitters: A report from the normative aging study. Addict Behav. 1992;17(4):367-77.

20. Borrelli B, Hogan JW, Block B, Pinto B, Roberts M, Marcus B. Predictors of quitting and dropout among women in a clinicbased smoking cessation program. Psychol Addict Behav. 2002;16(1):22-27.

21. Deheinzelin D, Lourenço MTC, Costa CL, Younes RN. The level of nicotine dependence is an independent risk factor for cancer: a case control study. Clinics. 2005;60(3):221-226. doi: 10.1590/ S1807-59322005000300007
22. Instituto Nacional de Câncer. Observatório da Política Nacional de Controle do Tabaco [citado 2015 Nov 6]. Disponível em: $<$ http://www2.inca.gov.br/wps/wcm/connect/observatorio_ controle_tabaco/site/home/dados_numeros/prevalencia-detabagismo>.

23. Santos SR, Gonçalves MS, Filho FSSL, Jardim JR. Perfil dos fumantes que procuram um centro de cessação de tabagismo. J Bras Pneumol. 2008;34(9):695-701.

24. Instituto Nacional de Câncer. Ministério da Saúde. Vigescola: vigilância de tabagismo em escolares. 2005 [citado 2015 Nov 6]. Disponível em: <http://www.inca.gov.br/vigescola>.

25. Figueiredo VC, Szklo M, Szklo AS, Benowitz N, Lozana JA, Casado $L$, et al. Determinants of salivary cotinine level: a population based study in Brazil. Rev Saúde Pública. 2007;41(6): 954-62. doi: 10.1590/S0034-89102006005000048

Received on: 10/9/2016 Final version resubmitted on:12/10/2016 Approved on: 10/1/2017 